\title{
Thyroid hormone export from cells: contribution of P-glycoprotein
}

\author{
A M Mitchell ${ }^{1,2}, \mathbf{M}$ Tom $^{1}$ and $\mathbf{R}$ H Mortimer ${ }^{1,3,4}$ \\ ${ }^{1}$ Conjoint Endocrine Laboratory, Royal Brisbane and Women's Hospital Research Foundation, Bancroft Centre, Brisbane, Queensland 4029, Australia \\ ${ }^{2}$ Queensland Health Pathology Service, Royal Brisbane and Women's Hospital, Brisbane, Queensland 4029, Australia \\ ${ }^{3}$ Department of Endocrinology, Royal Brisbane and Women's Hospital, Brisbane, Queensland 4029, Australia \\ ${ }^{4}$ Department of Obstetrics and Gynaecology, University of Queensland, Brisbane, Queensland 4029, Australia \\ (Requests for offprints should be addressed to R H Mortimer, Royal Brisbane and Women's Hospital, Base Hospitals, Herston, Queensland 4029, Australia; \\ Email: Robin Mortimer@health.qld.gov.au)
}

\begin{abstract}
Verapamil inhibits tri-iodothyronine $\left(\mathrm{T}_{3}\right)$ efflux from several cell types, suggesting the involvement of multidrug resistance-associated (MDR) proteins in $\mathrm{T}_{3}$ transport. The direct involvement of $\mathrm{P}$-glycoprotein (P-gp) has not, however, been investigated. We compared the transport of ${ }^{125} \mathrm{I}_{-} \mathrm{T}_{3}$ in MDCKII cells that had been transfected with mdr1 cDNA (MDCKII-MDR) versus wild-type MDCKII cells (MDCKII), and examined the effect of conventional (verapamil and nitrendipine) and specific MDR inhibitors (VX 853 and VX 710) on ${ }^{125} \mathrm{I}_{-} \mathrm{T}_{3}$ efflux. We confirmed by Western blotting the enhanced expression of P-gp in MDCKII-MDR cells. The calculated rate of ${ }^{125} \mathrm{I}_{-} \mathrm{T}_{3}$ efflux from MDCKII-MDR cells (around $0 \cdot 30 / \mathrm{min}$ ) was increased twofold compared with MDCKII cells (around $0 \cdot 15 / \mathrm{min}$ ). Overall, cellular accumulation of ${ }^{125} \mathrm{I}_{-} \mathrm{T}_{3}$ was reduced by $26 \%$ in MDCKII-MDR cells
\end{abstract}

compared with MDCKII cells, probably reflecting enhanced export of $\mathrm{T}_{3}$ from MDCKII-MDR cells rather than reduced cellular uptake, as P-gp typically exports substances from cells. Verapamil lowered the rate of ${ }^{125} \mathrm{I}_{-} \mathrm{T}_{3}$ efflux from both MDCKII and MDCKII-MDR cells by $42 \%$ and $66 \%$ respectively, while nitrendipine reduced ${ }^{125} \mathrm{I}_{-} \mathrm{T}_{3}$ efflux rate by $36 \%$ and $48 \%$ respectively, suggesting that both substances inhibited other cellular $\mathrm{T}_{3}$ transporters in addition to P-gp. The specific MDR inhibitors VX 853 and VX 710 had no effect of ${ }^{125} \mathrm{I}_{-} \mathrm{T}_{3}$ efflux rate from wild-type MDCKII cells but reduced ${ }^{125} \mathrm{I}_{-} \mathrm{T}_{3}$ export in MDCKII-MDR cells by $50 \%$ and $53 \%$ respectively. These results have provided the first direct evidence that $\mathrm{P}-\mathrm{gp}$ exports thyroid hormone from cells. Journal of Endocrinology (2005) 185, 93-98

\section{Introduction}

Thyroid hormone plays an essential role in mammalian cellular metabolism. While much is known about the physiology of trans-membrane iodothyronine transport (Kragie 1994, 1996, Abe et al. 2002) little is known about the molecular mechanisms of these processes. In addition to cellular uptake, export of thyroid hormone from cells may be an important factor in the regulation of thyroid hormone action at the level of its nuclear receptor (Ribeiro et al. 1996).

$\mathrm{P}$-glycoprotein (P-gp; multidrug resistance-associated (MDR)1) is a $170 \mathrm{kDa}$ surface glycoprotein found in a number of normal tissues and interacts with a broad range of substrates and inhibitors, including steroid hormones (Barnes et al.1996). P-gp pumps substrates in a single direction, out of cytoplasm, and is present in high levels in many multidrug-resistant cell lines and tumors. Verapamil-sensitive thyroid hormone efflux from cells has been reported in several cell types (Ribeiro et al. 1996, Neves et al. 2002) and, as verapamil is a potent inhibitor of
P-gp, this suggested involvement of the MDR transporters in the efflux of thyroid hormone. Verapamil is not, however, a specific inhibitor of $\mathrm{P}-\mathrm{gp}$ and it was also found to inhibit tri-iodothyronine $\left(\mathrm{T}_{3}\right)$ efflux from cells that did not express MDR1 (Cavalieri et al. 1999). Photoaffinity labelling of these latter cells with ${ }^{125} \mathrm{I}_{-} \mathrm{T}_{3}$ revealed a 90-100 kDa protein that interacted with $\mathrm{L}_{-} \mathrm{T}_{3}$ and verapamil. The small size of the protein excluded the possibility that it was P-gp and Cavalieri et al. (1999) concluded that a novel, verapamil-sensitive protein was responsible for $T_{3}$ export in these cells. Although the available evidence of verapamil-sensitive $T_{3}$ efflux from cells suggested that MDR transporters may be involved in exporting thyroid hormone out of cells, we identified a need for further investigations to clarify whether P-gp is indeed a mediator of cellular thyroid hormone efflux.

We investigated this by using a polarized MDCKII cell line that has been stably transfected with MDR1 cDNA (MDCKII-MDR). This is an established model for testing the transport functions of $\mathrm{P}-\mathrm{gp}$, We compared uptake and efflux of $\mathrm{T}_{3}$ in wild-type MDCKII cells (MDCKII) and 
transfected MDCKII cells (MDCKII-MDR). We confirmed interaction between thyroid hormone and P-gp by examining the effect of conventional (verapamil, nitrendipine) as well as novel (VX 853 and VX 710) inhibitors of P-gp-mediated transport on uptake and efflux of thyroid hormone in these cells. The results provide the first direct evidence that $\mathrm{P}-\mathrm{gp}$ is involved in the cellular export of thyroid hormone.

\section{Materials and Methods}

Materials were purchased from the following sources: ${ }^{125} \mathrm{I}_{-} \mathrm{T}_{3}(114 \mathrm{MBq} / \mu \mathrm{g})$ from Amersham Biosciences, Amersham, Bucks, UK; foetal calf serum (FCS) from JRH Biosciences, Lexena, KS, USA; six-well tissue culture plates from Costar, Cambridge, MA, USA; mouse antiP-gp antibody C219 from Signet Laboratories Inc., Dedham, MA, USA; BCA protein reagent from Pierce Chemicals, Rockford, IL, USA. MDR inhibitors VX 853 and VX 710 were a gift from Vertex Pharmaceuticals Inc., Cambridge, MA, USA. All other chemicals and cell culture media were from Sigma Chemical Co., St Louis, MO, USA.

\section{Cell culture}

The MDCKII cells (canine kidney cell line) and the MDCKII-derived cells, MDCKII-MDR, (stably transfected with mdr1 cDNA) were a gift from Professor $\mathrm{P}$ Borst, The Netherlands Cancer Institute, Amsterdam, The Netherlands, and have been described previously (Bakos et al. 1998). Cell lines were maintained in continuous culture at $37{ }^{\circ} \mathrm{C}$ in a humidified atmosphere of 95\% air and 5\% $\mathrm{CO}_{2}$. Culture medium was Dulbecco's modified Eagles' medium supplemented with $10 \%(\mathrm{v} / \mathrm{v})$ FCS. Cells were subcultured twice a week. For uptake and efflux experiments, cells were plated into six-well tissue culture plates and grown for 2-3 days until confluent. Medium was changed daily.

\section{Uptake and efflux studies}

Uptake studies were carried out as previously described (Mitchell et al. 1992, 1994, 1995). Briefly, prior to all experiments cells were incubated for $1 \mathrm{~h}$ in Hanks' balanced salt solution (HBSS). All incubations were carried out at $25{ }^{\circ} \mathrm{C}$. To study the time-course of cellular uptake, cells were incubated for $45 \mathrm{~min}$ in HBSS containing $30 \mathrm{pM}^{125} \mathrm{I}_{-} \mathrm{T}_{3}$ with or without $10 \mu \mathrm{M}$ excess unlabelled $\mathrm{T}_{3}$. Unlabelled thyroid hormone was dissolved in ethanol and diluted in HBSS. The final concentration of ethanol did not exceed $0 \cdot 4 \%$ and this had no effect on cellular uptake and efflux of ${ }^{125} \mathrm{I}-\mathrm{T}_{3}$. To terminate uptake, incubation medium was aspirated, cells were washed twice in ice-cold HBSS and immediately lysed in $1 \mathrm{M} \mathrm{NaOH}$.
Cell-associated activity was determined by counting the radioactivity in a Packard $\gamma$-counter with a counting efficiency of $84 \%$.

Washout studies were performed to determine whether the exit rate of ${ }^{125} \mathrm{I}_{-} \mathrm{T}_{3}$ from the cells was enhanced in MDCKII-MDR cells compared with wild-type MDCKII cells and whether it was affected by the presence of either unlabelled $\mathrm{T}_{3}$ or inhibitors in the external medium. The procedure used to study efflux was as described (Mitchell et al. 1994) with some modifications. Briefly, the cells were incubated for $45 \mathrm{~min}$ with $30 \mathrm{pM}^{125} \mathrm{I}_{-} \mathrm{T}_{3}$, washed in non-radioactive HBSS and then incubated for $45 \mathrm{~min}$ at $37^{\circ} \mathrm{C}$ in non-radioactive medium with or without $10 \mu \mathrm{M}$ unlabelled $\mathrm{T}_{3}, 100 \mu \mathrm{M}$ verapamil or nitrendipine (Sigma Chemical Co.) or $5 \mu \mathrm{M}$ VX 853 or VX 710. After 1, 2, 5, 10,15 and 30 min incubation medium was aspirated and replaced with fresh HBSS to prevent re-uptake of the hormone released into the medium. The amount of ${ }^{125} \mathrm{I}_{-} \mathrm{T}_{3}$ released from the cells in the presence of unlabelled $\mathrm{T}_{3}$ or an inhibitor during the 45-min incubation in non-radioactive medium and the cell-associated hormone were determined by counting the radioactivity in the aspirated media and the cell lysates respectively. ${ }^{125}$ I-labelled thyroid hormone tracer released in the presence of an inhibitor during the 45-min incubation in non-radioactive medium was compared with that released in the absence of an inhibitor. The exit rate constants were calculated by linear regression of the efflux data.

We sought evidence of metabolism of ${ }^{125} \mathrm{I}_{-} \mathrm{T}_{3}$ by duplicate cultures of MDCKII cells during uptake and efflux experiments by analysing radioactivity present in the cells and in the medium after incubation with the tracer for $45 \mathrm{~min}$ at $25^{\circ} \mathrm{C}$ by $\mathrm{LH}-20$ Sephadex chromatography (Otten et al. 1983).

\section{Plasma membrane isolation}

Plasma membrane proteins were isolated as described by Cavalieri et al. (1999). Cells were grown to confluence, washed and scraped in phosphate-buffered saline, harvested by centrifugation at $180 \mathrm{~g}$ for $2 \mathrm{~min}$ at $4{ }^{\circ} \mathrm{C}$ and resuspended in hypotonic buffer ( $1 \mathrm{mM}$ Tris, $\mathrm{pH}$ 7). Recombinant Serratia marcescens nuclease ( $800 \mathrm{U}$; benzonase) was added, and the mixture was stirred on ice for $2 \mathrm{~h}$. The cell lysate was centrifuged at $100000 \mathrm{~g}$ for $30 \mathrm{~min}$ at $4{ }^{\circ} \mathrm{C}$, and the resulting crude membrane pellet was resuspended in buffer $(50 \mathrm{mM}$ Tris and $50 \mathrm{mM}$ mannitol, $\mathrm{pH} 7 \cdot 0$ ). All solutions were supplemented with the proteinase inhibitors leupeptin $(4 \mu \mathrm{M})$, EGTA $(2 \mathrm{mM})$ and phenylmethylsulfonylfuoride $(0.5 \mathrm{mM})$. Aliquots were removed for determination of protein concentration.

\section{Electrophoresis and immunoblotting}

Plasma membrane proteins $(20 \mu \mathrm{g})$ isolated from MDCKII and MDCKII-MDR cells were dissolved in sample 


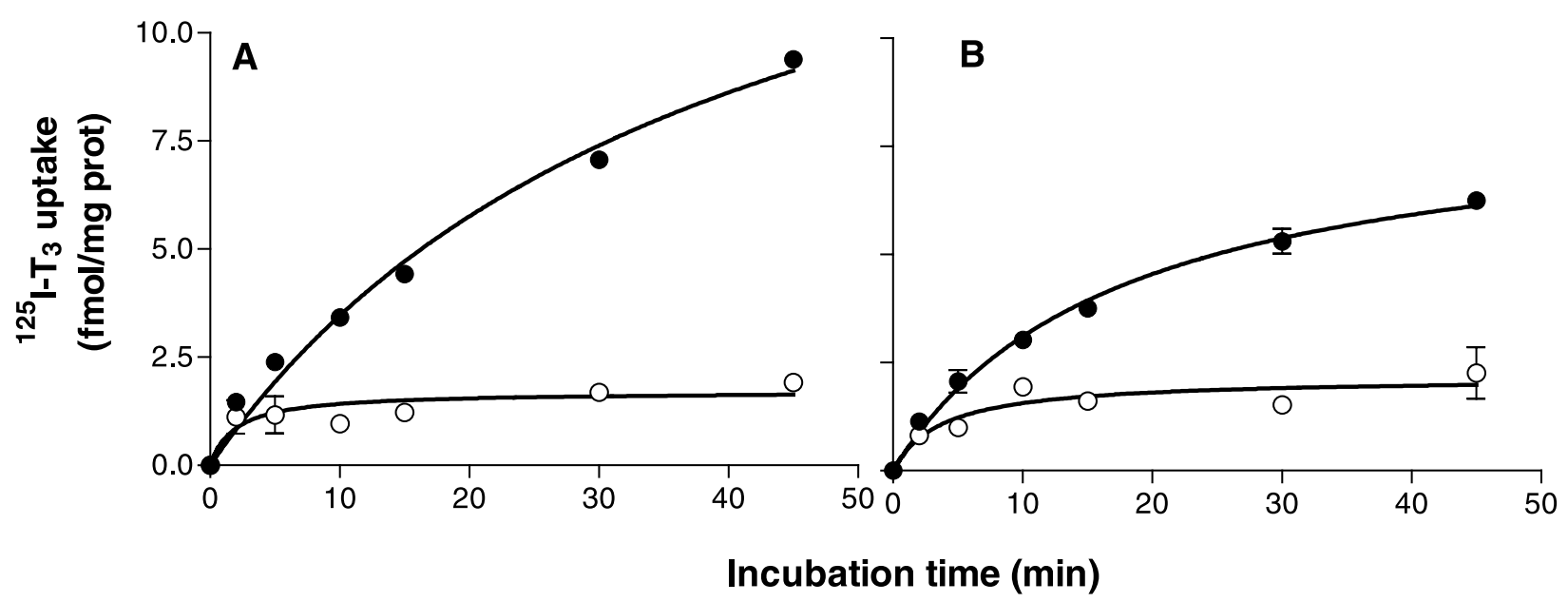

Figure 1 Western blot analysis of cell membrane proteins using the C219 mdr1/P-gp monoclonal antibody. Aliquots of $20 \mu \mathrm{g}$ plasma membrane protein isolated from MDCKII cells and MDCKII cells transfected with mdr1 cDNA were fractionated on 7.5\% SDS-PAGE and transferred to nitrocellulose. The blot was incubated with a 1:1000 dilution of a mouse monoclonal antibody, C219. The immune complexes were detected with the ECL Western blotting analysis system. Line 1, protein standards; line 2, MDCKII; line 3, MDCKII-MDR.

electrophoresis buffer $(2 \%(\mathrm{v} / \mathrm{v})$ SDS, $5 \%(\mathrm{v} / \mathrm{v})$ mercaptoethanol, 10\% (w/v) glycerol and $60 \mathrm{mM}$ Tris, $\mathrm{pH}$ 6.8), boiled for 5 min as described by Samson et al. (1993) and fractionated by electrophoresis on $7 \cdot 5 \%$ SDS-PAGE gels (1.5 mm thick) (Laemmli 1970). The molecular weight of the bands was estimated using pre-stained SDS-PAGE standards (BioRad, Hercules, CA, USA). The gel was transferred to nitrocellulose membrane by electroblotting (Towbin et al. 1979). The nitrocellulose membrane was incubated with a 1:1000 dilution of a mouse monoclonal antibody (C219) against the nucleotide-binding domain of human P-gp (Georges et al. 1990). Immune complexes were detected using the ECL Western blotting analysis system (Amersham).

\section{Determination of the cellular protein content}

The protein content of cell lysates and the the membrane protein preparation were determined with the BCA reagent, which is a modification of the Biuret reaction, using bovine serum albumin as a standard.

\section{Statistical analysis}

Statistical analysis was performed by Student's $t$-test. Results are expressed as means and standard errors of the mean; $n$ is the number of independent experiments, each in triplicate. A probability of $<0.05$ was regarded as significant.

\section{Results}

\section{Confirmation of expression of P-gp in MDCKII and} MDCKII-MDR cells

Immunoblots of plasma membrane proteins using a specific antibody against P-gp, C219, confirmed strong expression of $\mathrm{P}-\mathrm{gp}$ in MDCKII cells transfected with MDR1 cDNA (MDCKII-MDR) and weaker expression in the wild-type MDCKII cells (Fig. 1]). This pattern of expression correlated with the enhanced rate of $\mathrm{T}_{3}$ efflux from MDCKII-MDR cells compared with MDCKII cells (Fig. 2).

\section{Cellular uptake and export of thyroid hormones}

Uptake of ${ }^{125} \mathrm{I}_{-} \mathrm{T}_{3}$ into both MDCKII cells and MDCKIIMDR cells was time-dependent and saturable, being reduced in the presence of an excess of unlabelled ligand (Fig. 3). The overall cellular accumulation of ${ }^{125} \mathrm{I}_{-} \mathrm{T}_{3}$ was reduced from $6.77 \pm 0.52 \mathrm{fmol} / \mathrm{mg}$ protein $(n=5)$ in MDCKII cells to $5 \cdot 02 \pm 0.21 \mathrm{fmol} / \mathrm{mg}$ protein $(n=5)$ in MDCKII-MDR cells after $30 \mathrm{~min}$ of incubation $(P=0 \cdot 003)$, probably reflecting enhanced export of $\mathrm{T}_{3}$ from MDCKII-MDR cells rather than reduced cellular uptake. Efflux of ${ }^{125} \mathrm{I}_{-} \mathrm{T}_{3}$ was significantly enhanced in MDCKII-MDR cells compared with wild-type MDCKII cells (Fig. 2). The calculated rate of ${ }^{125} \mathrm{I}_{-} \mathrm{T}_{3}$ efflux from the intracellular compartment of MDCKII-MDR cells $(0 \cdot 276 \pm 0 \cdot 026 / \mathrm{min}, \quad n=5) \quad$ was increased twofold compared with MDCKII cells $(0 \cdot 134 \pm 0 \cdot 008 / \mathrm{min}, n=5)$.

Effect of verapamil, nitrendipine, VX 710 and VX 853 on cellular efflux of $T_{3}$

Verapamil lowered the rate of ${ }^{125} \mathrm{I}_{-} \mathrm{T}_{3}$ efflux from both MDCKII and MDCKII-MDR cells by around $42 \%$ and $66 \%$ respectively, while nitrendipine reduced ${ }^{125} \mathrm{I}_{-} \mathrm{T}_{3}$ efflux rate by $36 \%$ and $48 \%$ respectively (Fig. 4 ). VX 710 and VX 853 had no significant effect of $\mathrm{T}_{3}$ efflux from MDCKII cells, but reduced $\mathrm{T}_{3}$ export in MDCKII-MDR cells by around $50 \%$ (Fig. 4). 


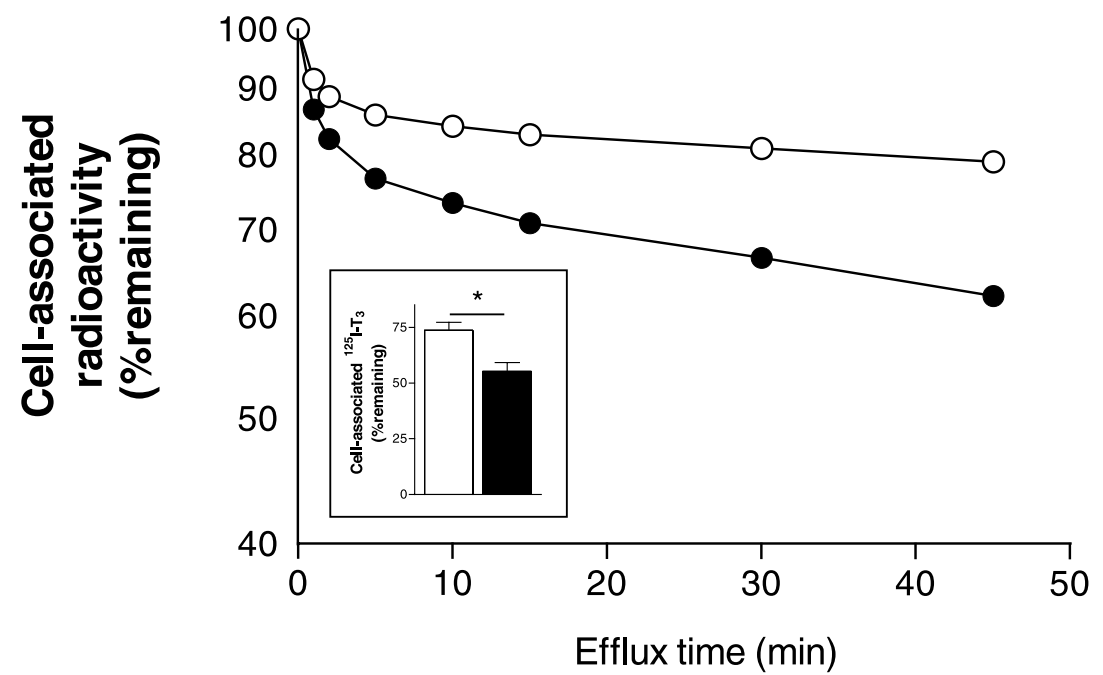

Figure 2 Export of ${ }^{125} \mathrm{I}-\mathrm{T}_{3}$ from MDCKII cells $(O)$ and MDCKII cells transfected with human mdr1 cDNA $(-)$. Cells were labelled by incubation for 30 min with $30 \mathrm{pM}^{125} \mathrm{I}^{-\mathrm{T}_{3}}$ washed, and then incubated again in non-radioactive medium for the indicated times as described in Materials and Methods. Values shown are means \pm S.E.M. $(n=3-5)$. Inset: \% cell-associated thyroid hormone remaining in MDCK II cells (open bar) and MDCKII-MDR cells (solid bar) after a 45-min washout in non-radioactive medium. Values are means \pm S.E.M. $(n=3-5) .{ }^{*} P<0 \cdot 01$.

\section{Metabolism of ${ }^{125}{ }^{2}-T_{3}$ by MDCKII cells}

Since MDCKII cells originate from dog renal epithelium, and kidney expresses type I deiodinase (Leonard \& Rosenberg 1978), we sought evidence of metabolism of ${ }^{125} \mathrm{I}_{-} \mathrm{T}_{3}$ in duplicate cultures of MDCK cells during uptake and efflux experiments by analysing the radioactivity present in the cells and the medium after incubation with the tracer for $45 \mathrm{~min}$ at room temperature. Intact hormone and metabolites were resolved by LH-20 Sephadex chromatography. We found only minimal evidence of

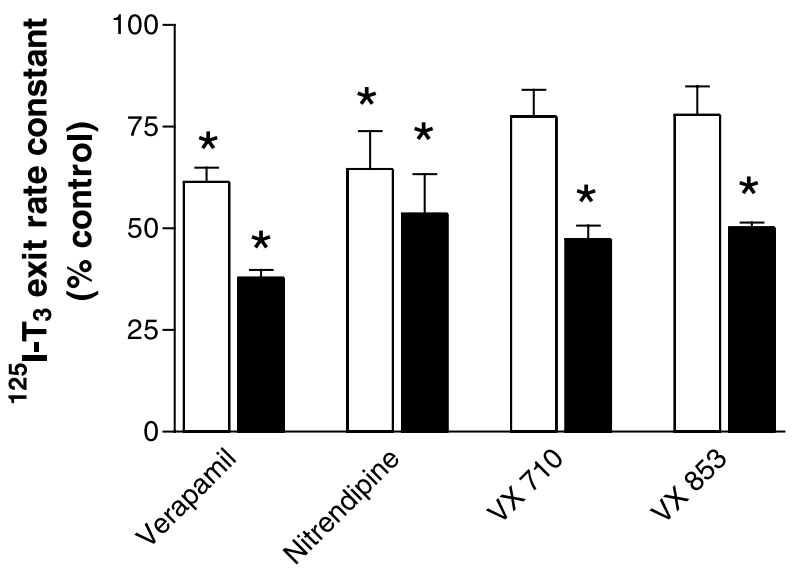

Figure 3 Time dependence of ${ }^{125} \mathrm{I}-\mathrm{T}_{3}$ uptake in the (A) MDCKII cells and (B) MDCKII cells transfected with human mdr1 cDNA. Cells were incubated at $25^{\circ} \mathrm{C}$ with $30 \mathrm{pM}^{125} \mathrm{I}-\mathrm{T}_{3}$ in the absence (-) or the presence $(O)$ of $10 \mu \mathrm{M}$ unlabelled $\mathrm{T}_{3}$. Values shown are means \pm S.E.M. $(n=3)$. metabolism of the tracer by the cells under the experimental conditions employed in our studies. The elution profiles indicated that over $90 \%$ of activity present in the medium and cells at the end of incubation was intact ${ }^{125} \mathrm{I}_{-} \mathrm{T}_{3}$.

\section{Discussion}

Thyroid hormones exert widespread influences on most mammalian tissues by genomic (via nuclear thyroid

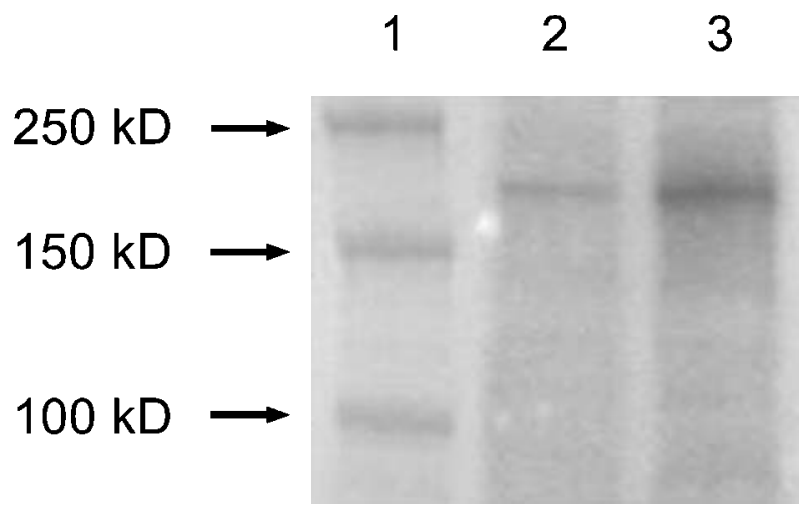

Figure 4 Effect of inhibitors on export of ${ }^{125} \mathrm{I}_{-} \mathrm{T}_{3}$ from MDCKII cells (open bars) and MDCKII cells transfected with human mdr1 cDNA (solid bars). Cells were labelled by incubation for $30 \mathrm{~min}$ with either $30 \mathrm{pM}^{125} \mathrm{I}-\mathrm{T}_{3}$ or $50 \mathrm{pM}^{125} \mathrm{I}-\mathrm{T}_{3}$, washed, and then incubated again in non-radioactive medium in the absence (control) or the presence of verapamil $(100 \mu \mathrm{M})$, nitrendipine $(100 \mu \mathrm{M})$, or P-gp inhibitors VX 710 and VX 853 (both $5 \mu \mathrm{M})$ for the indicated times. Values shown are means \pm S.E.M. $(n=4)$. 
hormone receptors) and non-genomic mechanisms. Thyroid hormone must enter the cell to bind to its nuclear receptor and there is extensive evidence that cellular transporters specific for thyroid hormone mediate hormone entry. Export of thyroid hormone may be an important factor regulating the intracellular content of hormone. Thyroid hormone transport across cell membranes has been studied extensively and much is known about the physiology of trans-membrane iodothyronine transport (Kragie 1994, 1996, Abe et al. 2002). There is, however, much less information about the molecular mechanisms mediating export of thyroid hormones from cells. We have shown previously that efflux of $\mathrm{T}_{3}$ from placental cells occurs via a saturable membrane transporter, which is trans-inhibited by $\mathrm{T}_{3}$ and tryptophan (Mitchell et al. 1994), but our previous studies did not provide information about the nature of this transporter. In the present study, we investigated whether thyroid hormones are exported from the cell by the MDR protein, $\mathrm{P}$-gp.

$\mathrm{P}-\mathrm{gp}$ is a $170 \mathrm{kDa}$ surface glycoprotein found in a number of normal tissues and in many multidrug-resistant cell lines and tumors. It interacts with a broad range of substrates, including steroid hormones (Barnes et al. 1996), and inhibitors, including calcium channel antagonists (Mickisch et al. 1990). Its greatest affinity is for large, hydrophobic cations. It pumps substrates in one direction, typically out of the cytoplasm. Several studies have attempted to examine the interaction of thyroid hormones with MDR proteins (Nelson \& Hinkle 1992, Ribeiro et al. 1996, Cavalieri et al. 1999, Neves et al. 2002). Inhibition of thyroid hormone efflux by verapamil has been reported in several cell types (Ribeiro et al. 1996, Neves et al. 2002). Since verapamil is a potent inhibitor of $\mathrm{P}$-gp (Mickisch et al. 1990) these results suggested the involvement of $\mathrm{P}$-gp in the efflux of thyroid hormone. $\mathrm{T}_{3}$ efflux from cell lines that do not express P-gp is, however, also inhibited by verapamil (Cavalieri et al. 1999). Photoaffinity labelling of these latter cells with ${ }^{125} \mathrm{I}_{-} \mathrm{T}_{3}$ revealed a $90-100 \mathrm{kDa}$ protein that interacts with $\mathrm{L}-\mathrm{T}_{3}$ and verapamil. The small size excluded the possibility that it was P-gp, indicating that a novel, as yet unidentified, verapamil-inhibitable protein was responsible for $\mathrm{T}_{3}$ export in these cells.

While previous studies provided some evidence suggesting interaction between MDR proteins and thyroid hormone export from cells, they either used drug-selected cell lines (Ribeiro et al. 1996) or primary cells (Neves et al. 2002) that expressed multiple MDR transporters in addition to P-gp. In addition, the calcium channel blocker verapamil, which is not selective for MDR, was used as an inhibitor of MDR transport. We have previously shown in the human choriocarcinoma cell line, JAR, significant inhibition of both uptake and efflux of $\mathrm{T}_{3}$ by calcium channel blockers nitrendipine and verapamil (Mitchell et al. 1999). JAR cells express minimal levels of P-gp (Mylona et al. 1996, Atkinson et al. 2003). In contrast, in the present study we used a polarized cell line,
MDCKII-MDR derived from an MDCKII cell line, stably transfected with mdr1 (P-gp) cDNA (Evers et al. 1997, 2000), and over-expressing P-gp (Borst et al. 1999). We also used two novel and specific inhibitors of MDR transport, VX 853 and VX 710 as well as the less specific calcium channel blockers verapamil and nitrendipine which are conventionally used as inhibitors of P-gp. A similar approach has been successfully employed to examine interactions of P-gp and cytotoxics used clinically, in which an earlier generation P-gp reversal agent, V-104 (Vertex Pharmaceuticals), effectively inhibited daunorubicin and vinblastine transport in MDCKII-MDR cells (Evers et al. 2000).

Using Western blot analysis of the plasma membrane proteins with an anti-P-gp monoclonal antibody C219, we confirmed residual $\mathrm{P}$-gp expression previously reported in the wild-type MDCKII cells (Goh et al. 2002) as well as the expected higher expression of P-gp in the MDCKIIMDR cells (Fig. 1). Cellular accumulation of $\mathrm{T}_{3}$ by MDCKII-MDR was markedly reduced when compared with the wild-type MDCKII cells (Fig. 3). This was most likely due to enhanced export of thyroid hormone from transfected cells rather than reduced uptake, since P-gp mediates unidirectional outward transport of substances from cells. Significantly enhanced efflux of thyroid hormones from MDCKII-MDR cells compared with wild-type MDCKII cells (Fig. 2) further suggested involvement of $\mathrm{P}-\mathrm{gp}$ in the export of thyroid hormones. We have also shown a significant reduction in the rate of $\mathrm{T}_{3}$ release from MDCKII-MDR cells in the presence of the calcium channel blockers, verapamil and nitrendipine, and the specific MDR inhibitors, VX 710 and VX 853, directly confirming the involvement of $\mathrm{P}-\mathrm{gp}$ in the export of $\mathrm{T}_{3}$ from the cell. Verapamil and nitrendipine inhibited the rate of efflux of $\mathrm{T}_{3}$ from both the wild-type MDCKII and the MDCKII-MDR cells, confirming the nonspecific inhibition of cellular $T_{3}$ transporters by these compounds. In contrast, neither VX 710 nor VX 853 had any significant effect on $T_{3}$ efflux from wild-type MDCKII cells, but reduced the rate of $\mathrm{T}_{3}$ efflux from MDCKII-MDR cells by around 50\% (Fig. 4).

In addition to inhibiting the activity of P-gp, both VX 710 and VX 853 also interact with another MDR protein, MRP1 (personal communication, C Sorensen, Vertex Pharmaceuticals). Wild-type MDCKII cells have relatively low levels of endogenous expression of functional MRP1 (Goh et al. 2002). Transfected and wild-type cells would be expected to have similar expression of MRP1 so the failure of VX 710 and VX 853 to inhibit thyroid hormone efflux in wild-type cells (Fig. 4) excludes MRP1 as a significant thyroid hormone export molecule in transfected cells.

Collectively, the results of the present study provide the first direct evidence of the involvement of $\mathrm{P}$-gp in thyroid hormone export from cells. MDR transporters may participate in the cellular transport of thyroid hormone in 
tissues that express them and provide a tissue-specific mechanism for the regulation of thyroid hormone action at the nuclear receptor level.

\section{Acknowledgements}

We thank Dr Craig Sorensen of Vertex Pharmaceuticals, USA and Professor Piet Borst of the Netherlands Cancer Institute for the gifts of MDR reversal agents VX 710 and VX 853, and MDCKII and MDCKII-MDR cell lines respectively. We also thank Professor Simon W Manley of The University of Queensland for critically reading the manuscript.

\section{Funding}

This work has been funded in part by the Royal Brisbane Hospital's Endocrinology Research Unit Trust Fund. There are no conflicts of interest that would prejudice impartiality of this article.

\section{References}

Abe T, Suzuki T, Unno M, Tokui T \& Ito S 2002 Thyroid hormone transporters: recent advances. Trends in Endocrinology and Metabolism 13 215-220.

Atkinson DE, Greenwood SL, Sibley CP, Glazier JD \& Fairbairn LJ 2003 Role of MDR1 and MRP1 in trophoblast cells; elucidated using retroviral gene transfer. American Journal of Physiology - Cell Physiology 285 C584-C591.

Bakos E, Evers R, Szakacs G, Tusnady GE, Welker E, Szabo K, de Haas M, van Deemter L, Borst P, Varadi A \& Sarkadi B 1998 Functional multidrug resistance protein (MRP1) lacking the N-terminal transmembrane domain. Journal of Biological Chemistry 273 32167-32175.

Barnes KM, Dickstein B, Cutler GB Jr, Fojo T \& Bates SE 1996 Steroid treatment, accumulation, and antagonism of $\mathrm{P}$-glycoprotein in multidrug-resistant cells. Biochemistry 35 4820-4827.

Borst P, Evers R, Kool M \& Wijnholds J 1999 The multidrug resistance protein family. Biochimica et Biophysica Acta 1461 347-357.

Cavalieri RR, Simeoni LA, Park SW, Baxter JD, Scharschmidt BF, Ribeiro RC \& Lomri N 1999 Thyroid hormone export in rat FRTL-5 thyroid cells and mouse NIH-3T3 cells is carrier-mediated, verapamil-sensitive, and stereospecific. Endocrinology 140 4948-4954.

Evers R, Cnubben NH, Wijnholds J, van Deemter L, van Bladeren PJ \& Borst P 1997 Transport of glutathione prostaglandin A conjugates by the multidrug resistance protein 1. FEBS Letters 419 112-116.

Evers R, Kool M, Smith AJ, van Deemter L, de Haas M \& Borst P 2000 Inhibitory effect of the reversal agents V-104, GF120918 and Pluronic L61 on MDR1 Pgp-, MRP1- and MRP2-mediated transport. British Journal of Cancer 83 366-374.
Georges E, Bradley G, Gariepy J \& Ling V 1990 Detection of P-glycoprotein isoforms by gene-specific monoclonal antibodies. PNAS 87 152-156.

Goh LB, Spears KJ, Yao D, Ayrton A, Morgan P, Roland Wolf C \& Friedberg T 2002 Endogenous drug transporters in in vitro and in vivo models for the prediction of drug disposition in man. Biochemical Pharmacology 64 1569-1578.

Kragie L 1994 Membrane iodothyronine transporters. Part I: Review of physiology. Endocrine Research 20 319-341.

Kragie L 1996 Membrane iodothyronine transporters, Part II: Review of protein biochemistry. Endocrine Research 22 95-119.

Laemmli UK 1970 Cleavage of structural proteins during the assembly of the head of bacteriophage T4. Nature 227 680-685.

Leonard JL \& Rosenberg IN 1978 Thyroxine 5'-deiodinase activity of rat kidney: observations on activation by thiols and inhibition by propylthiouracil. Endocrinology 103 2137-2144.

Mickisch GH, Kossig J, Keilhauer G, Schlick E, Tschada RK \& Alken PM 1990 Effects of calcium antagonists in multidrug resistant primary human renal cell carcinomas. Cancer Research $\mathbf{5 0}$ 3670-3674.

Mitchell AM, Manley SW \& Mortimer RH 1992 Uptake of L-tri-iodothyronine by human cultured trophoblast cells. Journal of Endocrinology 133 483-486.

Mitchell AM, Manley SW \& Mortimer RH 1994 Interactions between transport of triiodothyronine and tryptophan in JAR cells. Molecular and Cellular Endocrinology 101 203-210.

Mitchell AM, Manley SW, Payne EJ \& Mortimer RH 1995 Uptake of thyroxine in the human choriocarcinoma cell line JAR. Journal of Endocrinology 146 233-238.

Mitchell AM, Rowan KA, Manley SW \& Mortimer RH 1999 Comparison of mechanisms mediating uptake and efflux of thyroid hormones in the human choriocarcinoma cell line, JAR. Journal of Endocrinology 161 107-113.

Mylona P, Glazier JD, Greenwood SL, Sides MK \& Sibley CP 1996 Expression of the cystic fibrosis (CF) and multidrug resistance (MDR1) genes during development and differentiation in the human placenta. Molecular Human Reproduction 2 693-698.

Nelson EJ \& Hinkle PM 1992 Characterization of multidrug-resistant pituitary tumor cells. Endocrinology 130 3246-3256.

Neves FA, Cavalieri RR, Simeoni LA, Gardner DG, Baxter JD, Scharschmidt BF, Lomri N \& Ribeiro RC 2002 Thyroid hormone export varies among primary cells and appears to differ from hormone uptake. Endocrinology 143 476-483.

Otten MH, Mol JA \& Visser TJ 1983 Sulfation preceding deiodination of iodothyronines in rat hepatocytes. Science 221 81-83.

Ribeiro RC, Cavalieri RR, Lomri N, Rahmaoui CM, Baxter JD \& Scharschmidt BF 1996 Thyroid hormone export regulates cellular hormone content and response. Journal of Biological Chemistry 271 17147-17151.

Samson M, Osty J \& Blondeau JP 1993 Identification by photoaffinity labeling of a membrane thyroid hormone-binding protein associated with the triiodothyronine transport system in rat erythrocytes. Endocrinology 132 2470-2476.

Towbin H, Staehelin T \& Gordon J 1979 Electrophoretic transfer of proteins from polyacrylamide gels to nitrocellulose sheets: procedure and some applications. PNAS 76 4350-4354.

Received 28 November 2004

Accepted 13 January 2005 